\title{
Siberian Identity in Traditions and Innovations of Art Culture
}

\author{
Marina V. Moskalyuk and Anastasiya P. Grishchenko* \\ Dmitri Hvorostovsky Siberian State Academy of Arts \\ Krasnoyarsk, Russian Federation
}

Received 13.03.2020, received in revised form 05.06.2020, accepted 15.06.2020

\begin{abstract}
The article considers the transformation of visual signs reflecting the Siberian identity. The phenomenon of the Siberian identity could be seen at some aspects of visual arts: the primitive art of petroglyphs, ethnographic elements of indigenous art and the legacy of the Siberian artist V.I. Surikov. Based on the philosophical and art history analysis of art works some visual signs of the studied aspects were identified, such as primitive pictures of people, ethnic clothing and patterns and, the painting "The Capture of the Snow Town" by V. Surikov. The most innovative ways of their interpretation in the modern cultural process have been identified. The article considers major Siberian festivals (for example Siberian Maslenitsa and the Krasnoyarsk Universiade), computer graphics, work of clothing designers and design of the facilities of the Krasnoyarsk Universiade. This study has resulted in understanding that there are certain visual signs that carry the burden of the formation of the regional Siberian identity in modern cultural processes.
\end{abstract}

Keywords: Siberian identity, visual arts, transformation of visual language, Siberian art, petroglyphs, ethnographic elements, culture proses.

Research area: fine and decorative arts and architecture.

Citation: Moskalyuk, M.V., Grishchenko, A.P. (2020). Siberian identity in traditions and innovations of art culture. J. Sib. Fed. Univ. Humanit. Soc. Sci., 13(6), 914-923. DOI: 10.17516/1997-1370-0615.

(C) Siberian Federal University. All rights reserved

* Corresponding author E-mail address: nr@kgii.ru ORCID: 0000-0003-4254-8384 (Moskalyuk); 0000-0001-8446-6163 (Grishchenko) 


\section{Introduction}

The development of self-awareness, patriotism and the formation of a sense of regional identity among the citizens have been the most important areas of the state policy (Ukaz Prezidenta RF ot 19 dekabrya 2012 g. N 1666). The issue of the regional (Siberian in our case) identity is quite urgent in connection with the search for new ways to maintain the cultural stability of the territory, because Yenisei Siberia today is a multi-ethnic region, where the development and formation of various ideals takes place.

Human self-consciousness is formed by various means, the most important of which are culture in general and art in particular. We think that it is important to turn to visual arts, since a person gets more than $70 \%$ of vital information through visual signs. Moreover, visual information perceived through art, through an artistic image has a unique ability to influence. Therefore, the relevance of the study of those signs of visual arts that are markers of the Siberian regional identity is obvious.

In the framework of this study, the goal is to identify the most effective, innovative ways of representing the Siberian identity through art. Based on the foregoing, the main tasks are to search in the history of Siberian art for those visual samples that have survived to this day and are firmly integrated into the culture, to consider their specifics and analyse their existence in modern times. Such an approach makes it possible not only to trace the basic transformations of expressively - figurative language, but also to identify those qualities of regional identity that are relevant in modern society.

\section{Conceptological basis for the study}

The concept of regional identity in the literature has been investigated quite thoroughly. Regional identity can be defined as a form of some self-presentation which allows one person or community of people to assess their position in relation to the outside world (Malkova, Tishkov, 2009). The constructivist approach gives an idea of its multiplicity and various practices that influence its formation (Khukhlaev, Khait, 2012). When forming images of regional iden- tity, the most significant factors according to the academician V.A. Tishkov (Tishkov, 2017) are the natural and cultural landscape, famous monuments of natural and cultural heritage, historical and political events related to geographical sites on the map, biographies of famous people (Malkova, Tishkov, 2009).

The actual Siberian identity was studied by such scientists as A.A. Anisimova, A.O. Boronoev, O.G. Echevskaya, E.E. Dutchak, N.V. Sverkunova, E.A. Gerasimova and N.P. Koptseva. Most of them believe that the formation of the Siberian community is associated with geographic (huge territories, remoteness from the centre), climatic, cultural (interaction of different cultures and beliefs) and historical factors (Boronoev, 2010). The difficulty in identifying the individual components lies in the synthetic nature, the inextricability of the links between various signs of the regional self-identification of the individual. One of the principles for identifying and consolidating the Siberian identity are socio-cultural practices, including works of art. Art culture, in this case, becomes, on the one hand, a mediator, and on the other, a reflection of the components of the regional identity.

The studies in the field of regional art culture were carried out by M.V. Moskalyuk, T.M. Lomanova, N.P. Koptseva, V.I. Zhukovsky, A.A. Semenova, K.V. Reznikova, N.N. Pimenova, A.V. Kistova, E.A. Sertakova, E.V. Golovneva and others. Art culture and creativity, as its component, can have a big impact on people's consciousness, change the perception of the surrounding reality, reflect the mood of political ideology and the image of a particular culture constant in a certain period of time.

\section{Problem statement}

This article proposes to consider three aspects of the Siberian identity related to the field of visual arts: the primitive art of petroglyphs, ethnographic elements of indigenous art, and the legacy of the most famous Siberian artist V.I. Surikov. Currently, these cultural strata are the most significant for the self-identification of a resident of the Yenisei Siberia. Their presence can be seen in various types of modern culture and art. 


\section{Discussion}

The presence of ancient settlements is evidenced by petroglyphs located in southern and eastern Siberia. The Krasnoyarsk artist V.F. Kapelko made a major contribution to the study and copying of ancient petroglyphs. His method of copying on mikalent paper is suitable not only for the transfer and preservation of ancient drawings, but also for exhibition purposes. The presentation of ancient cave paintings to the viewers enables Siberians to use one of the aspects of regional identity: their attitude to the territory and its history. Presentation of ancient petroglyphs almost in their original form in expositional conditions builds the relationship of the viewer with ancient artists, their way of life and beliefs, and the culture of the indigenous people. Identification of the territories where the copies were made, provides the individual with an understanding of the historical importance of the land where they live.

Already in the $80 \mathrm{~s}-90 \mathrm{~s}$ of the $20^{\text {th }}$ century, Vladimir Feofanovich Kapelko, not only copied, but also created paintings using the visual language of ancient art. In the work "Shishkinskaya Pisanitsa" (1990), the artist depicts the famous cave paintings of the Palae- olithic Epoch updating their meaning: ancient drawings dominate the work. Visual signs are transformed from simple copying (on mikalent paper) to the means of depicting a historical event, the means of creating an artistic image in a work of art. It looks like the ancient nomads continue their journey in our time, linking different layers of history.

The contemporary existence of visual signs of primitive Siberian art - petroglyphs can be seen in the works of many modern artists. Sergey Anufriev, an academician of the Russian Academy of Arts, Honoured Artist of the Russian Federation, often turns to rock paintings in his sculptures, installations and objects of decorative and applied art. In his work "12 Shamans" (2016, enamel), the iconography of rock paintings is clearly represented, but at the same time saturated, often contrasting colours are used, texture and motif of movement, changes and transformation appear (Fig. 1). Ancient anthropomorphic and geometric motifs take the form of modern art and are transformed into relevant images in demand by today's audience.

Searching for the Siberian artistic identity in the 1980s, Nikolai Rybakov, a well-known

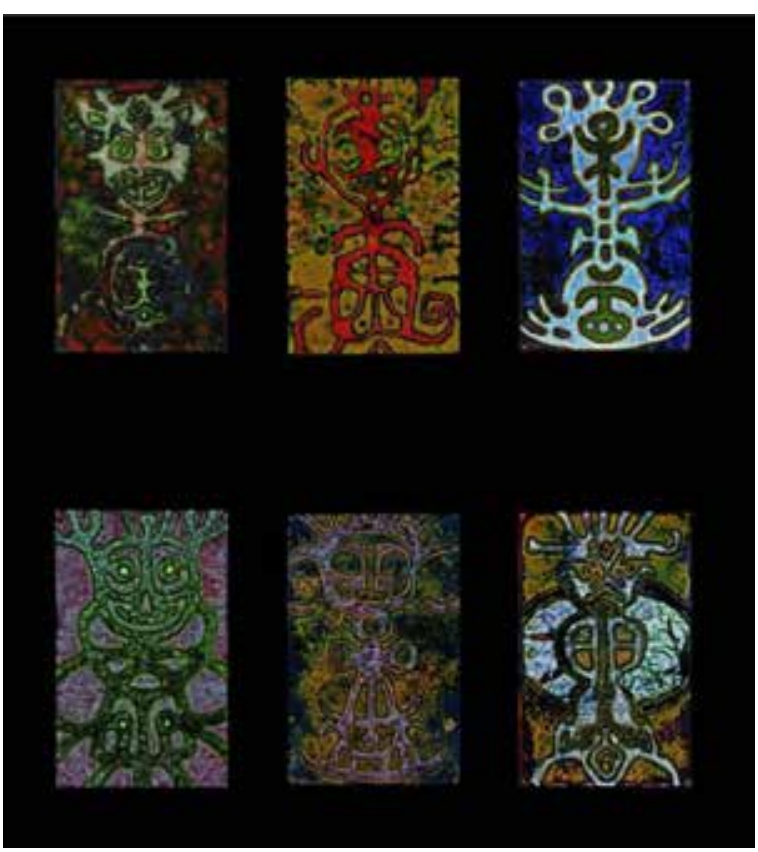

Fig. 1. S.E. Anufriev "12 shamans" 
Siberian painter and graphic artist, turns to archaeological and ethnographic material, travels a lot across Siberia from Taimyr to Tuva, and takes part in expeditions. His early works based on ethnographic observations, reflect an interest in ancient sites and cave paintings (Lomanova, 2009). In the works "Nomads" (1989, oil on canvas) and "Green Encampment" (1990, oil on canvas), the artist uses the visual signs of cave paintings: the archetypal image of a person, his sketchy image (Fig. 2). The main thing is the colour and texture of the canvas. Here bright, but not contrasting (brown and green) colour solutions are presented. The appeal to cave paintings and the use of one colour dominant form a visual statement that addresses the culture of ancient settlements. However, the predominance of abstraction over realism and texture over content gives the primitive visual code a new, modern tone. On the one hand, the compositions draw the viewer's attention to the historical value of the territory, its saturation with great events, and on the other, its vitality and uniqueness in the modern world. The interpretation of the primitive visual language has undergone the way from a simple typical image to abstract art. However, it continues to transmit the meaning of Siberia as one of the cradles of mankind and makes it possible to see oneself as a resident of an ancient land with a rich history.

A new trend, conditionally named ethno-archaic, took shape and actively declared itself in the visual arts of Siberia of the last quarter of the $20^{\text {th }}$ century, which evidences the demand for and emotional rethinking of the ancient signs of our land by modern culture. The expressive language and imagery in the works of ethno-archaic is built on the artistic and aesthetic development of the heritage of ancient Siberian civilisations. The most striking example of the transformation of a petroglyph in a modern context is the "Concept of Visual Identity of the Krasnoyarsk Airport" developed by the Art Style Group (Fig. 3).

According to the systematisation by E.V. Golovneva (Golovneva, 2018), an ethnocultural narrative accounts for $10 \%$ of the definition of the term "Siberian" and is an important component of the Siberian identity. The Krasnoyarsk Krai is home for representatives of more than 150 nationalities (Amosova et al., 2019). The first images of indigenous peoples in Siberian art can be found in V.I. Surikov's works, in his watercolours and picturesque sketches made during his travels in Khakassia. Since then, the ethnographic motif has firmly entered the visual language of Siberian

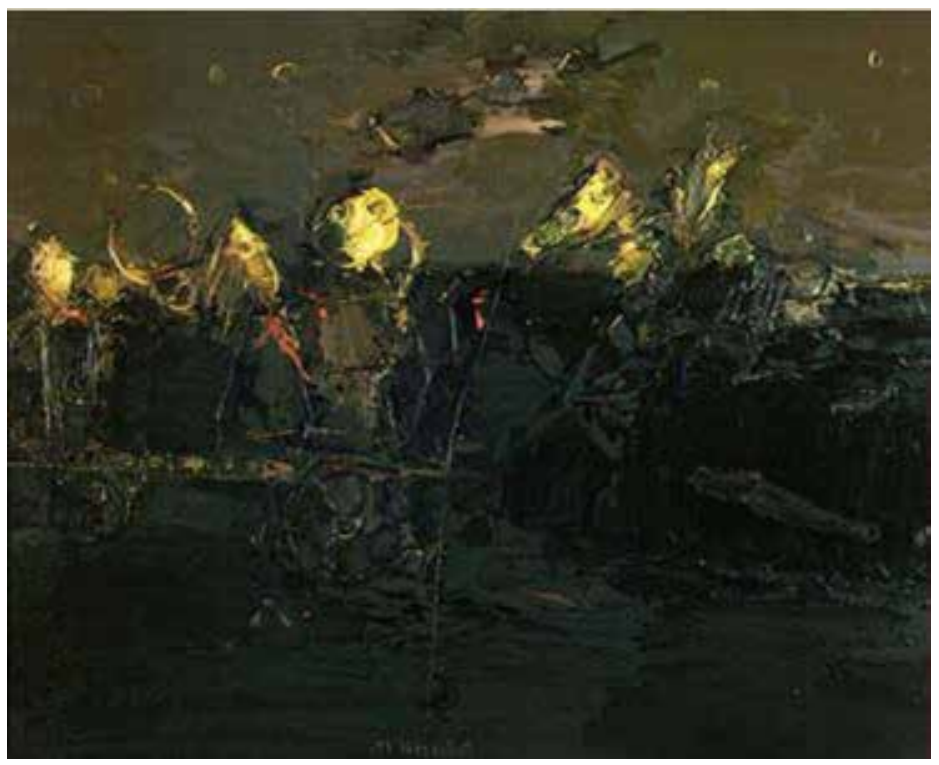

Fig. 2. N. Rybakov "Nomads" 


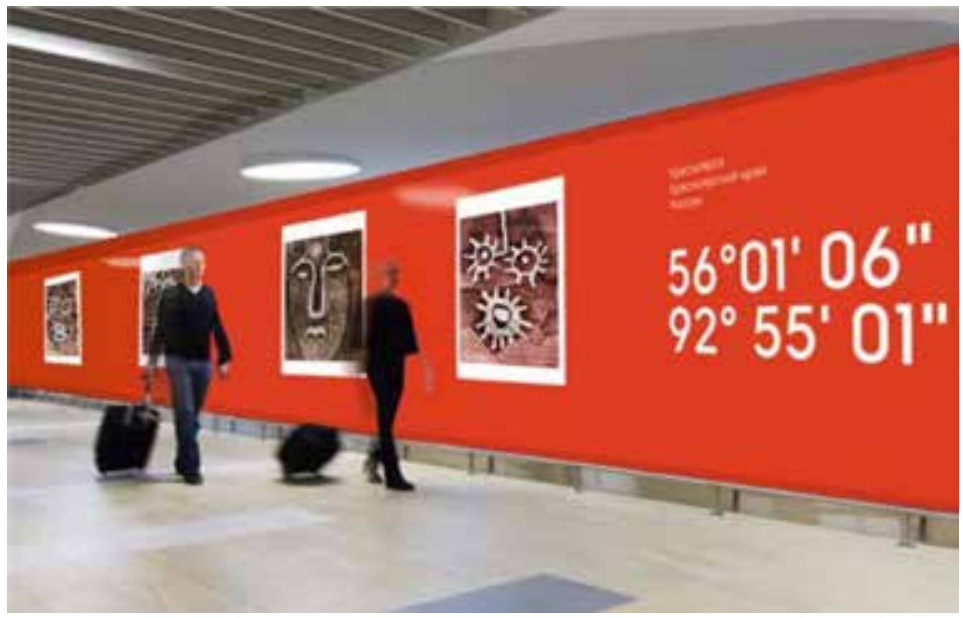

Fig. 3. The concept of visual identity of the Krasnoyarsk Airport

art and has become a part of the formation of the Siberian identity by means of visual arts. Ethnographic motifs can be found in the works of many Krasnoyarsk artists: A.P. Lekarenko, T.V. Ryannel, V.F. Kapelko, A.A. Dovnar, V.T. Bashmakov, G.G. Gorensky, K.S. Voinov, V.I. Meshkov and others. Elements of clothing and life, patterns and deer represent the traditional recognition of indigenous peoples, and, accordingly, of the north of Siberia in the visual arts.

In a series of etchings "The Youth of Taimyr", S.F. Turov uses not only everyday life and clothing of indigenous peoples, but also mythological elements: in the upper part of the sheets "Dream" and "Song" (1978, Krasnoyarsk Art Museum named after V.I. Surikov) there are images of inverted deer that turn us to the Upper World. According to the beliefs of indigenous peoples, the Upper World is like an inverted land, which takes the viewer to the legends and tales of the north (Fig. 4). Each sheet of the series is a whole universe where characters live, where "the nature and traditions of the past are an integral part of human being" (Bulak, 2018).

The work by A.A. Dovnar "Nganasan Pipes" (1973, oil on canvas, Krasnoyarsk Art Museum named after V.I. Surikov) is quite fascinating, where the central element is the traditional Nganasan kumalan rug. The kumalan circle defines a circular composition, collects all other objects around a single centre with the tobacco pouch and pipes lying around it, i.e. a meeting of close friends is observed here $(\mathrm{Bu}-$ lak, 2018). This work transmits peace and tranquillity. The objects used in the work have an ethnic context that is noticeable to an ordinary viewer, and the general atmosphere of friendship is interpersonal relations, both within the same nationality and in the region as a whole. The matches and the metal tobacco pouch indicate the use of Russian household items in the everyday life of indigenous peoples, which also demonstrates their co-presence and cohabitation in the same territory. The viewer of this work, recognising the signs of the language, feels this atmosphere and joins in with understanding the importance of participation in other nationalities (Fig. 5).

Among the young generation, one can single out the works by Evgeny and Yuliya Porotovs, whose works appeal to the Dolgan culture. Their creative interests include experiments in the field of arts and crafts, various graphic techniques and computer graphics. The latter gives the traditional motifs of indigenous peoples a modern tone. The use of folklore and fairy tales to create illustrations filled with the aesthetics of comics, computer games and modern animation, demonstrates a new round of understanding the role of the northern peoples in modern art culture. The illustrations that represent the originality of the Dolgans, at the same time, 


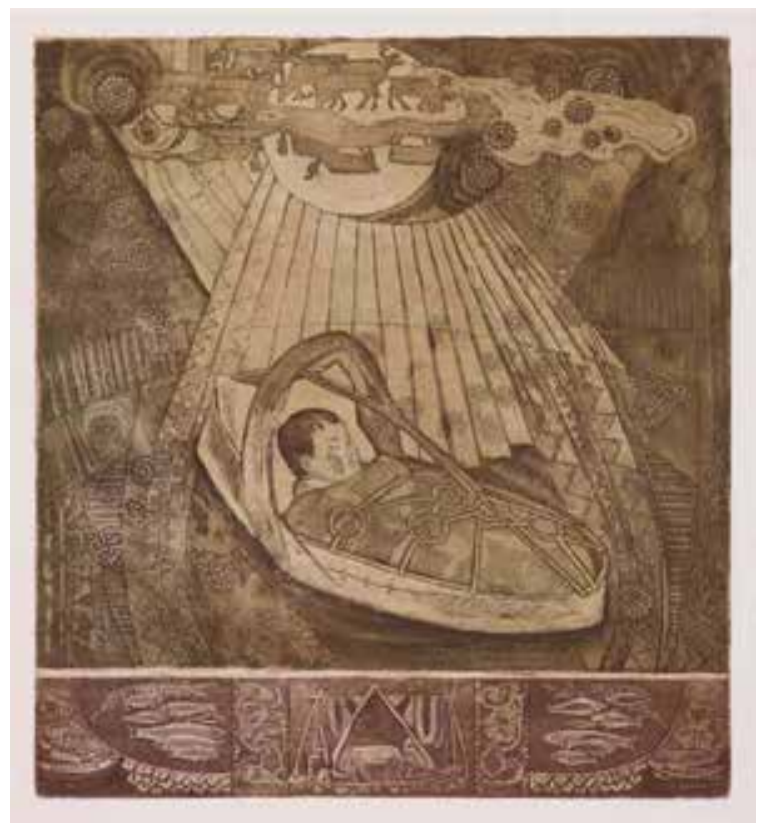

Fig. 4. S.F. Turov "Dream". Series "The Youth of Taimyr"

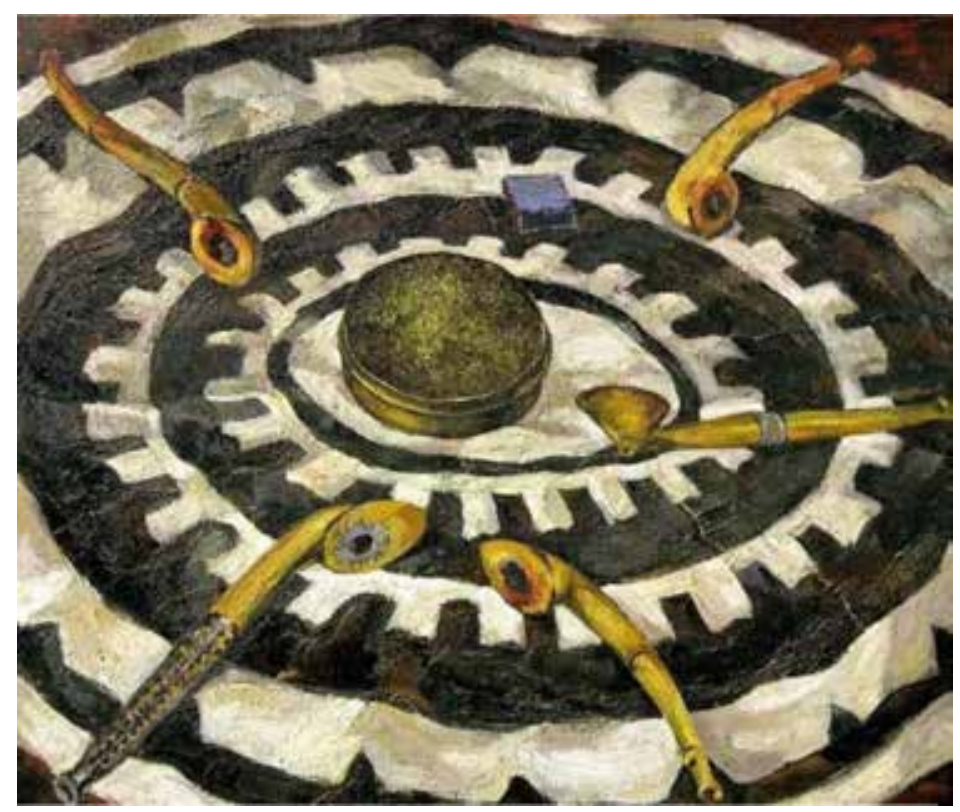

Fig. 5. A.A. Dovnar "Nganasan Tobacco Pipes"

are indicators of the Siberian identity, where Siberia appears as an ethnocultural region, which is home to a large number of different ethnic groups. The illustration for the Dolgan fairy tale "Diga Baba" from the book "Folklore of the Dolgan of the Khatanga Tundra" (2016, computer graphics) is a complex visual image where the ethnic and the modern were mixed. The fairy tale itself tells the story of the hero Aiyy protecting the Middle World from the 
Lower World and killing the evil being raised by Diga Baba. The hero himself, depicted in the illustration twice, by the power of visual signs appears as a warrior-saviour, a modern super-hero in an ethnic costume. Diga Baba, the shaman, is represented with her attributes during the shaman's ritual (Fig. 6). The combination of several scenes within the framework of one artistic image provides the viewer with the opportunity to see all the main characters of the fairy tale and to update the traditions of indigenous peoples in modern culture.

A series of "Rovduga" addresses the archaic sources of the Dolgan cosmology. The work "Osuokhkay" ("Circle Dance"; collage, mixed techniques, 2014) presents the cosmology of the Dolgan people, their customs. The actualisation of the Dolgan epic in this case is expressed both in materials (dressed leather, wood, threads) and in embroidered drawings, peculiar "patches" with the images of people. Different colours and shapes of stripes, but a single pictorial system represent a generalised image of Siberia - co-participation in a single "round dance of life" (Fig. 7).
Today, not only direct references to indigenous peoples are actively used, but also national patterns: in clothes, footwear and hats. The pictorial language of the art of indigenous peoples has firmly entered the outline of the social life of the Siberian, and is already perceived as 'local'. A variety of festivals are held annually, the most famous of which is the "World of Siberia", an international festival of ethnic music and crafts, which is currently becoming one of the main cultural events of the Krasnoyarsk Krai.

The Siberian community enshrined in the cultural code, manifests itself in the national vibrant holiday of Maslenitsa, which culminates with the game 'The Capture of the Snow Town'. The folk game long gone into oblivion, has become a symbol of Siberian festivities, thanks to the painting of the same name by V.I. Surikov (1891, oil on canvas. State Russian Museum, St. Petersburg). The artist reflected in his work the joy and brightness of the Siberian holiday. Creating the work, he used all the rich material that the city of Krasnoyarsk gave him at the end of the 19th century: the costumes

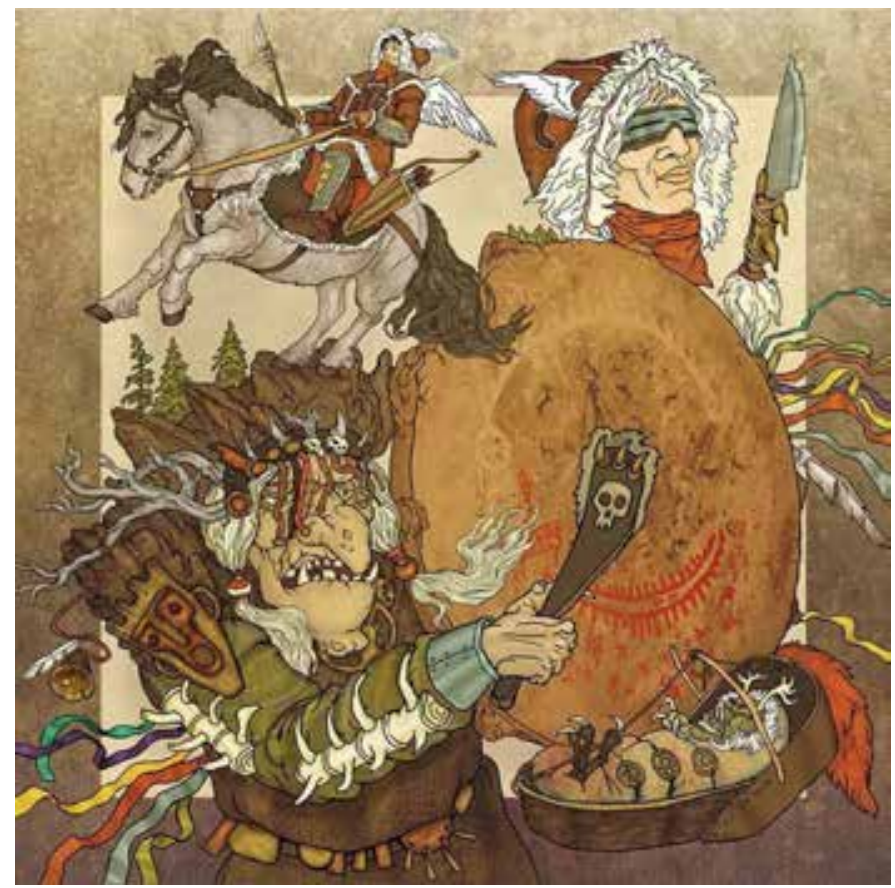

Fig. 6. E. and Yu. Porotovs. “Diga Baba”. Illustration to the book "Folklore of the Dolgan of the Khatanga Tundra" 


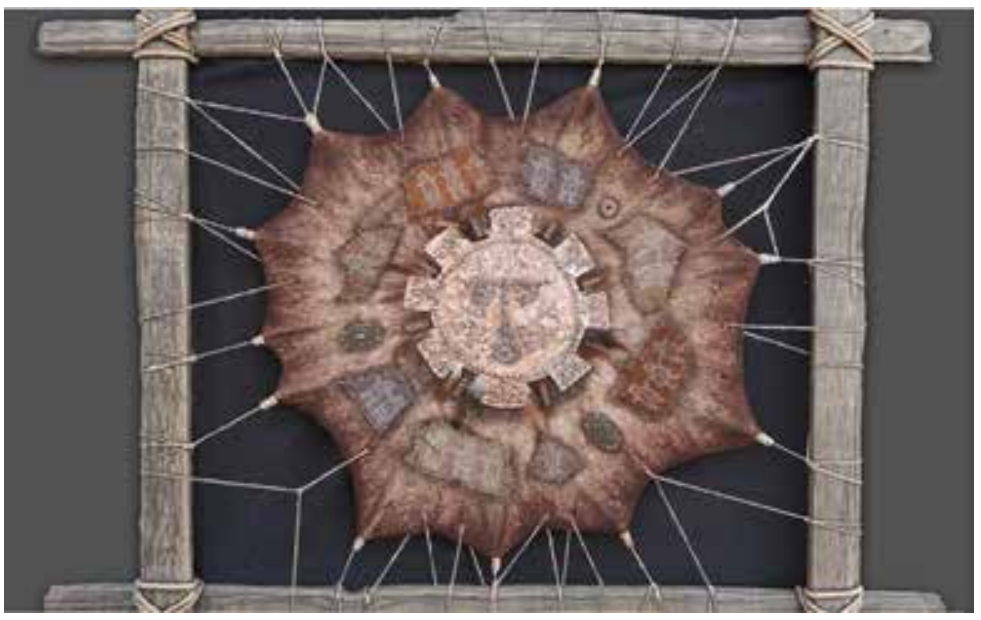

Fig. 7. E. and Yu. Porotovs “ Osuokhkay” (“Circle Dance”)

of the townspeople that he sketched at fairs, horse decorations, and of course, the Cossack recklessness of Siberian residents. The brightest and most cheerful work by V.I. Surikov became a visiting card of Siberia: the names of the Krasnoyarsk people depicted in the picture, the specific place where the artist painted the landscape, the traditions of festive celebrations are known. Thanks to the artistic image of "The Capture of the Snow Town" painting, a chain is formed that reveals the regional identity of the modern Siberian: reading the signs of the visual language contributes to the formation of the image of Siberia at the end of the 19 th century, the feeling of belonging to the region and the city, correlating oneself with the author and heroes of the work, awareness of involvement in culture contributes to the formation of a stable socio-cultural context of the personal perception of the viewer. The levels of correlating oneself (Kistova, 2018) with the presented event reveal the basic principles of the formation and reflection of the regional Siberian identity in the visual arts.

"The Capture of the Snow Town" by Surikov allows us to see innovative ways to consolidate the images and ideas of works of visual arts in modern cultural practice. The Siberian Maslenitsa and saying farewell to winter, which has already become a traditional holiday, has been celebrated annually in the Siberian region since 2008. The main event, i.e. the game of capturing the snow town, is held in the village of Sukhobuzimo, Krasnoyarsk Krai, where the atmosphere is recreated, enshrined in the work by V.I. Surikov. The 2019 Winter Universiade Park is quite remarkable in this aspect as it hosted not only Maslenitsa festivities, but also provided everyone with an opportunity to become the hero of the famous painting, the Cossack who broke the snow fortress. A special interactive platform allowed one to become the hero of the picture, to try on the outfits of that time and to play the show. Such use of the famous work of art gives the viewer an opportunity to be imbued with its imagery and become part of not only the picture, but also the holiday itself, which means "a true Siberian". This example clearly shows how outstanding artistic images influence the formation of regional identity.

\section{Conclusion}

Presented visual complexes, namely, ancient petroglyphs, ethnographic motifs, Surikov's painting "The Capture of the Snow Town" have their own history of existence in Siberian culture and are its traditional components. It was not our goal to comprehensively study them, as the main idea for us was to trace their modern interpretation, to reveal the actualisation of the meanings that they contain. In the formation of the Siberian identity, each of the three components considered has its own load. Petroglyphs in their numerous modern 
transformations make it possible to understand the depth of historicity of the Siberian land. The whole diversity of the use of ethnographic motifs in artistic innovations allows us to feel as locals in a wide circle of the peoples of Siberia, these are like various forms of inclusion in the symbolic "peace pipe". Strength, scope and recklessness transmitted through various forms of "The Capture of the Snow Town" allow one to try on the Siberian character. The visual signs fixed in time are transformed according to the requirements of modern society and continue their mission: providing the opportunity to feel like part of the Siberian region and a real Siberian through the artistic image of the work of visual arts.

\section{References}

Amosova, M.A., Koptseva, N.P., Sitnikova, A.A., Seredkina, N.N., Zamaraeva, Y.S., Kistova, A.V., ... \& Pimenova, N.N. (2019). Ethnocultural Identity in the Works of Krasnoyarsk Artists. In Journal of Siberian Federal University. Humanities \& Social Sciences, 8(12), 1524-1551.

Boronoev, A.O. (2010). Problemy dinamiki sibirskoi identichnosti [Problems of the dynamics of Siberian identity]. In Obshhestvo. Sreda. Razvitie (Terra Humana) [Society. Environment. Development], 3.

Bulak, K.A. (2018). Sever v tvorchestve khudozhnikov Krasnoiarskogo kraia. Iz sobraniia Krasnoiarskogo khudozhestvennogo muzeia imeni V.I. Surikova. Al'bom-katalog [North in the work of artists of the Krasnoyarsk Territory. From the collection of the Krasnoyarsk Art Museum named after V.I. Surikov. Catalog album], Krasnoyarsk, 144 p.

Golovneva, E.V. (2018). Konstruirovanie regional'noi identichnosti v sovremennoi kul'ture (na materiale Sibirskogo regiona): dissertatsiia na soiskanie uchenoi stepeni doktora filosofskikh nauk.

Khukhlaev, O.E., Khait, M.A. (2012). Slozhnost' sotsial'noi identichnosti: kontseptsiia S. Rokkas i M. Briuer [The complexity of social identity: the concept of S. Rokkas and M. Brewer]. In Sotsialnaia psikhologiia i obshhestvo [Social Psychology and Society], 3, 16-26.

Kistova, A.V. (2018). Slozhnaia sotsial'naia identichnost' kak osnova transformatsii khudozhestvennykh traditsii [Complex social identity as the basis for the transformation of artistic traditions]. In Nauchnoe nasledie II Soktoevoi v svete aktual'nykh problem sovremennogo izobrazitel'nogo iskusstva [The scientific heritage of II Soktoeva in the light of the pressing problems of modern art], 162-169.

Lomanova, T.M. (2009). Nikolai Rybakov: "... Between the Abyss and the Heaven”.

Malkova, V.K., Tishkov, V.A. (2009). Obrazy rossiiskikh respublik v internete [Samples of Russian republics on the Internet] (1). In Kul'tura i prostranstvo [Culture and space], Moscow, IAE RAN, 147 p.

Tishkov, V.A. (2017). Chto est' natsiya. V poiskax rossiiskoi identichnosti [What is a nation. In search of Russian identity]. In Nezavisimaia gazeta [Independent newspaper], 24, 9. 


\title{
Сибирская идентичность в традициях и новациях художественной культуры
}

\section{М.В. Москалюк, А.П. Грищенко}

Сибирский государственный институт искусств

имени Дмитрия Хворостовского

Российская Федерачия, Красноярск

\begin{abstract}
Аннотация. Целью данной статьи является рассмотрение трансформации визуальных знаков, отражающих сибирскую идентичность. В рамках исследования обозначены три аспекта сибирской идентичности, связанные со сферой изобразительного искусства: первобытное искусство петроглифов, этнографические элементы искусства коренных народов и наследие крупнейшего сибирского художника В.И. Сурикова. На основе философско-искусствоведческого анализа были выявлены визуальные знаки исследуемых аспектов и представлены наиболее новационные способы их интерпретации в современном культурном процессе. В работе рассмотрены произведения как традиционного искусства: живописные и графические работы В. Сурикова, В. Капелько, А. Довнара, С. Турова, так и современные практики их изменения: творчество современных художников С. Ануфриева, Н. Рыбакова, Е. и Ю. Поротовых, фестиваль «Сибирская Масленица», работы дизайнеров одежды и визуальное оформление объектов Красноярской Универсиады. Основным выводом, сформированным в работе, является наличие в современных культурных процессах определенных визуальных знаков, несущих в себе нагрузку формирования региональной сибирской идентичности.
\end{abstract}

Ключевые слова: региональная идентичность, визуальные искусства, трансформация визуального языка, искусство Сибири, петроглифы, этнографические элементы, культурный процесс.

Научная специальность: 17.00.04 - изобразительное и декоративно-прикладное искусство и архитектура. 